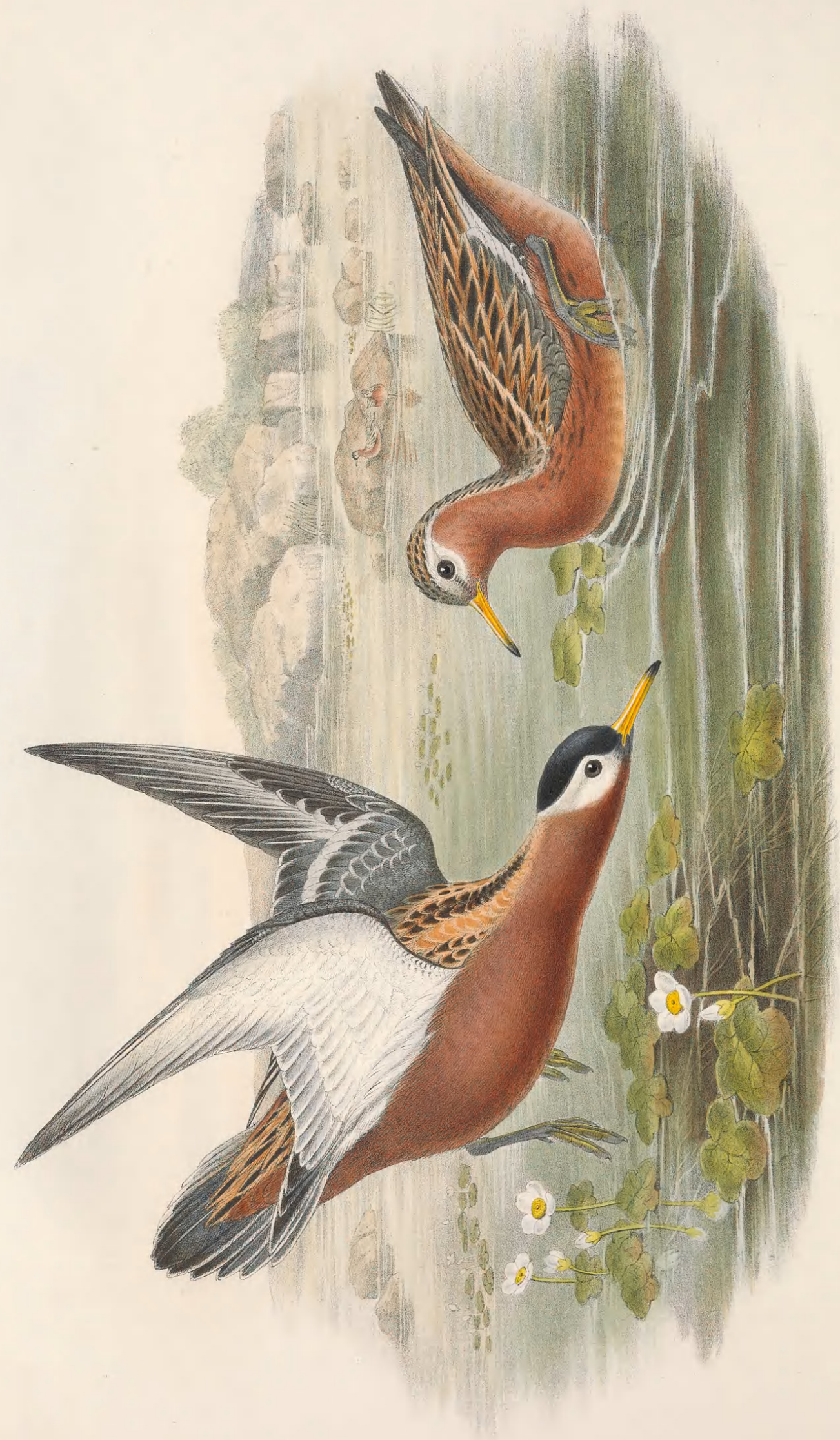

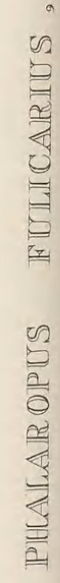




\section{PHALAROPUS FULICARIUS.}

\section{Grey Phalarope.}

Tringa fulicaria, Linn. Syst. Nat., tom. i. p. 249.

lobata, Linn. Faun. Suec., p. 64.

glacialis, Gmel. edit. Linn. Syst. Nat., tom. i. p. 675

Crymophilus rufus, Vieill. Nouv. Dict. d'Hist. Nat., tom. viii. p. 521.

Phalaropus lobatus et glacialis, Lath. Ind. Orn., tom. ii. p. 776. griseus, Leach, Syst. Cat. of Indig. Mamm. and Birds in Brit. Mus., p. 34. platyrhynchos, Temm. Man. d'Orn., 1st edit. p. 459. fulicarius, Bonap. Geogr. and Comp. List of Birds of Eur. and N. Amer., p. 54. rufescens, Keys. \& Blas. Wirbelth. Eur., p. 73

rufus, Bechst. Naturg. Deutschl., tom. iv. p. 381.

The accompanying Plate will give that portion of my readers who may not be intimately acquainted with this Phalarope a better idea of the bird than the most minute verbal description. It has obtained its trivial name of Grey from the circumstance of its being most commonly in its light winter dress when seen in this country, a costume widely different from that of spring and summer, represented on the annexed illustration. That the bird should be subject to so great a transformation is indeed astonishing; but so it is, and, this being the case, it would have been quite as appropriate to call it the Red as the Grey Phalarope; a trivial name, however, which has become universal cannot well be altered, or surely the summer or finest state of plumage ought to be indicated in its common designation rather than the grey and unattractive one of winter.

After these remarks on the name of this interesting species, I commence its history by asking, Of what country is it a native? and shall proceed to give all the information I have been able to collect respecting its habits and economy. Its true domicile is clearly not the British Islands ; neither does it pass the summer or breed to the southward of the arctic circle, except on rare occasions. Is it not, then, a native of that portion of our globe which has hitherto defied the energies of civilized man to penetrate, the extreme north, within that great belt of congelation of which we have as yet only reached the outer edge, probably amid open waters studded with islands which afford congenial summer homes to many other birds whose true breeding-grounds yet remain to be discovered (the Rosy Gull of Ross, the Sanderling, Grey Plover, \&c.)? Whoever may have the good fortune to lift this veil of mystery will, I believe, see the breedingcountry of several of our winter migrants. For if there be not such an asylum for these birds in the high northern regions, I know not whither they can betake themselves for the performance of the duty of reproduction. The Grey Phalarope is said to breed in Iceland and Greenland, and on the North Georgian and Melville Islands. Spitzbergen and Nova Zembla have also been enumerated as among its breeding-places; but all that could be produced in these localities would not be sufficient to form the great number of individuals that resort to countries further south during the period of winter, or for the rast flights that every now and then are seen passing over Europe, Asia, and America. To England its visits are uncertain, and when it does come it is generally in small numbers; but I am prepared to show that vast flights of these fairy-like birds do now and then arrive. Fairy-like, indeed, are these little travellers ; for the delicate white and grey colouring of their feathers, the tameness of their disposition, their elegant mode of flight, and chaff-like buoyancy as they topple on the waters like a reversed feather from a Swan's breast, justifies such a comparison. The extreme tameness they display is alone sufficient to tell us that they have come from a country where man, not being a denizen, has neither impressed them with fear, nor disturbed them in their breeding-quarters. They seem to have arrived from some blissful elysium where peace and quietude reign, and now for the first time to meet with their greatest enemy and certain destroyer. Mr. Gatcombe informs me that a few Grey Phalaropes visit the coast of Devonshire almost every year, and may be found, if looked for, during the autumnal equinoxes, swimming in an elegant and graceful manner amid the patches of foam and weed collected just outside the breakers, nimbly searching for food, nodding their heads, and wheeling about like feathers on the water. At such times they are exceedingly regardless of man, and, if shot at and missed, will often give only a little spring in the air, and then resume their feeding as if nothing had happened. Some years ago an immense flight of these birds appeared on the coasts of Devon and Cornwall, filling the bays and inlets all along the shore, and at times were seen in flocks running about the grass on the low cliffs like Sandpipers. A few were noticed on inland ponds and all kinds of strange places. So numerous were they in Plymouth Sound, that near the entrance of the Catwater I sav a man shooting them with an old rusty musket, and cramming his pockets full; upon asking what he 
intended doing with so many, he replied, "They make capital pies!" I could have killed any number, but contented myself with obtaining sufficient to supply my numerous ornithological friends. This great flight appeared in October, and many of the old birds retained traces of the plumage of the preceding summer. The first time a great number of Phalaropes were observed at Plymouth was about thirty-five years ago, when a dead whale was brought into the Sound, to which circumstance their appearance was attributed; but as the occurrence took place in autumn, it is probable the whale had nothing to do with it.

To give all the instances on record of the capture of this bird in England would be as superfluous as it is impossible to say on what particular day or in which week of the year a living bird may be seen on our coast or inland waters; for its appearance is governed by circumstances unknown to us. And, indeed, the Grey Phalarope must be regarded as an accidental visitor, as a bird which may perhaps be met with at the Land's End, on the coast of Norfolk, on the Thames, the Ribble, or the Humber, or a sheet of water in a nobleman's park, or a large reservoir (like that at Kingsbury in Middlesex), or on a horse-pond by the roadside, any day during the seasons of autumn and winter. Its appearance in Ireland and Scotland is precisely similar, as it also is in all parts of the continent, and all the northern portions of the globe from the latitude of the Mediterranean; further south than this it seldom proceeds, and necessity alone impels it to wander thus far from its true home. Rarely, if ever, is it seen in this country in its red or nuptial dress; but traces of its assumption have been seen in the few examples killed in spring, and traces of its remains in those shot in autumn, as mentioned by $\mathrm{Mr}$. Gatcombe.

There are two or three circumstances connected with this bird which are very remarkable. In the first place, the female is both larger in size, and in summer is more gaily attired than the male-a difference which is shown in the accompanying Plate, where the bird figured in the act of flying, represents a female, and that on the water a male; in the next, I am informed by Professor Steenstrup, of Copenhagen, that the duty of incubation appears to be performed by the male only-a circumstance which appears to be confirmed by the bare state in which the breasts of specimens of that sex are often found. We know that this duty is executed by the male Rheas and Emus; and it is stated that the male Turnices, which are also smaller than the females, hatch the eggs and take charge of the young exclusively; but that such a habit should prevail with the Phalaropes is a singular anomaly.

Mr. Newton, in his valuable Notes on the Birds of Iceland, published in Baring-Gould's 'Iceland, its Scenes and Sagas,' says, "This bird has been but seldom observed by strangers in Iceland, yet in 1858 I found it was very well known to the natives in the district where Faber had seen it in 1821 . On the 21 st of June in that year he obtained a pair which were swimming in a flock of the commoner species (Lobipes hyperboreus). The female contained largely developed eggs. On the following day he found a single pair near the same locality, but searched in vain for their nest. Finally he met with a family party some miles to the eastward. In $1858 \mathrm{I}$ discovered two pairs on a lake in the same district; but a few days afterwards they had disappeared, and they certainly did not remain to breed there that year. Last summer, a friend of mine sent me four eggs as those of this bird, which had been taken under his special superintendence. Setting aside the excellent authority on which their identification rests, they are so entirely different from any other Icelandic bird's I know, that I can hardly doubt their genuineness."

In his notes on the birds in Spitzbergen, Mr. Newton says, "Although met with in various localities, from the extreme south to the extreme north, and doubtless breeding in many places, the exact spots selected are still unknowu to us. Dr. Malmgren was as unsuccessful in his first voyage as myself. Last year the skipper of a Swedish exploring vessel found a nest with four eggs up the North Fjord of the Sound, at the beginning of July. The contents he put in his cap ; but as he was deer-stalking at the time, he forgot the treasures he was carrying, and they were all smashed. Later in the month Professor Dunér found a nest, with three fresh eggs, in Bell Sound. They lay on the ground, which consisted of small splinters of stone, without any bedding. They are now at Stockholm. Neither of the parent birds was observed near the nest. Dr. Malmgren noticed this species as far north as lat. $80^{\circ} 10^{\prime}$. He states it feeds chiefly on a species of Nostoc; but the stomachs of those I dissected on Russö contained many guats and their larvæ.

"Mr. Holboll says that it is the latest of all the Greenland birds, and does not arrive till the beginning of June, at which time it may be seen in large flocks in Davis Straits. In his voyage to Greenland, in 1835, whilst shut up in the ice for eighteen days, he saw this bird swimming about among the blocks of ice. In South Greenland it is rarely seen, and then only in its migration southward. In North Greenland it is very common, and builds its nest there on nearly all the islands possessing small ponds. Whilst the Red-necked Phalarope always resorts to those islands which are within the fjords, this species as constantly breeds upon those only which are outside the coast. In August the young ones are fledged, and in September they are seen in company with the old birds, all in their winter clothing, swimming about the outermost islands, where they seek out the bays, and delight very much in playing about in the broken water."

The front figures are of the natural size. The plant is the Ramunculus fluviatilis. 


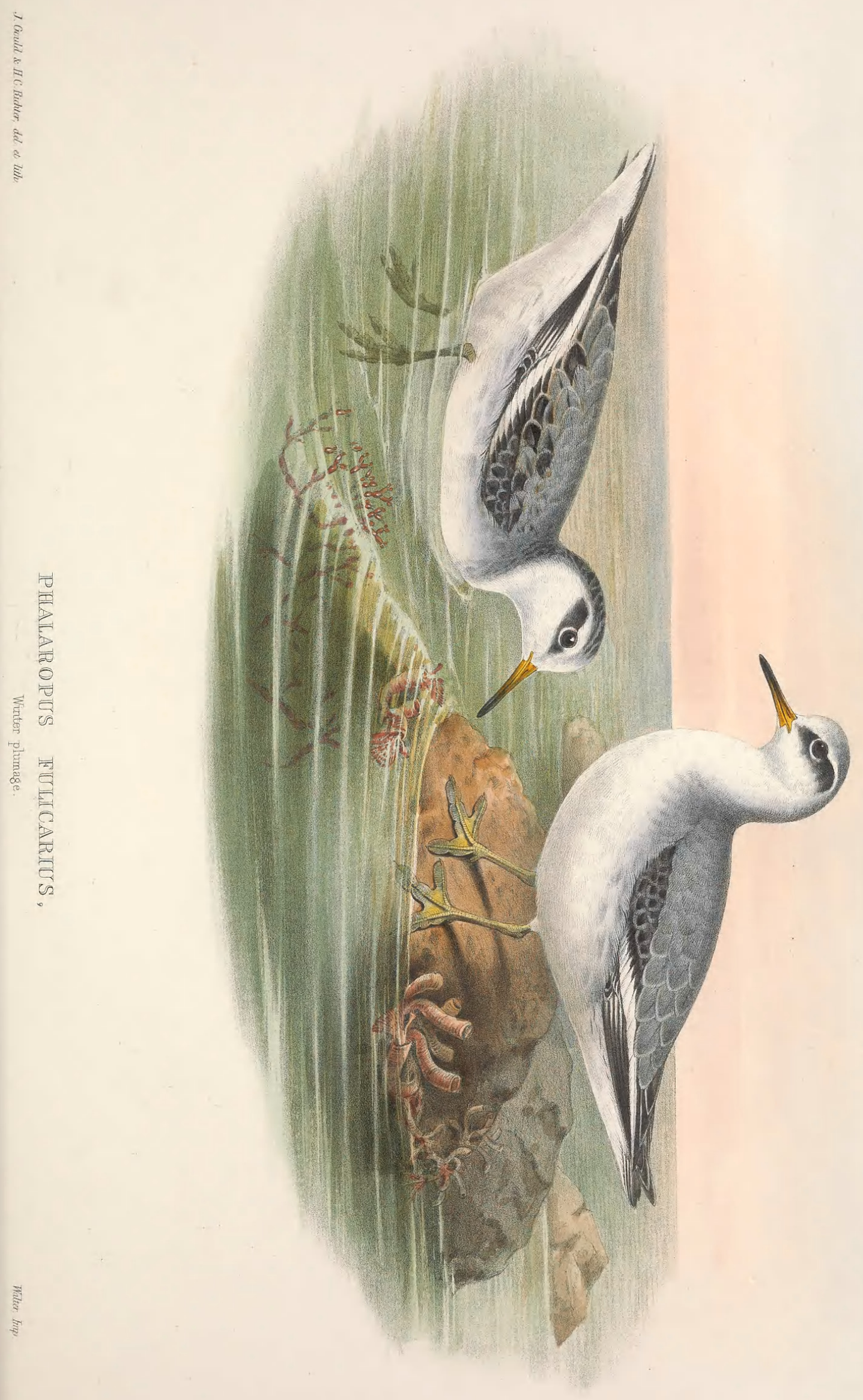




\section{$2 \mathrm{BHL}$ Biodiversity Heritage Library}

Gould, John. 1873. "Grey Phalarope, Phalaropus fulicarius [PI. 81-82]." The birds of Great Britain 4, -. https://doi.org/10.5962/p.324036.

View This Item Online: https://www.biodiversitylibrary.org/item/221609

DOI: https://doi.org/10.5962/p.324036

Permalink: https://www.biodiversitylibrary.org/partpdf/324036

\section{Holding Institution}

Smithsonian Libraries

\section{Sponsored by}

Biodiversity Heritage Library

\section{Copyright \& Reuse}

Copyright Status: Public domain. The BHL considers that this work is no longer under copyright protection.

This document was created from content at the Biodiversity Heritage Library, the world's largest open access digital library for biodiversity literature and archives. Visit BHL at https://www.biodiversitylibrary.org. 